\title{
The mixing state of carbonaceous aerosol particles in northern and southern California measured during CARES and CalNex 2010
}

\author{
J. F. Cahill ${ }^{1}$, K. Suski ${ }^{1}$, J. H. Seinfeld ${ }^{2}$, R. A. Zaveri ${ }^{3}$, and K. A. Prather ${ }^{1,4}$ \\ ${ }^{1}$ Dept. of Chemistry and Biochemistry, University of California San Diego, CA, USA \\ ${ }^{2}$ Division of Chemistry and Chemical Engineering, California Institute of Technology, Pasadena, CA, USA \\ ${ }^{3}$ Atmpspheric Sciences \& Global Division, Pacific Northwest National Laboratory, Richland, WA, USA \\ ${ }^{4}$ Scripps Institute of Oceanography, University of California San Diego, La Jolla, CA, USA
}

Correspondence to: K. A. Prather (kprather@ucsd.edu)

Received: 12 July 2012 - Published in Atmos. Chem. Phys. Discuss.: 27 July 2012

Revised: 2 November 2012 - Accepted: 14 November 2012 - Published: 21 November 2012

\begin{abstract}
Carbonaceous aerosols impact climate directly by scattering and absorbing radiation, and hence play a major, although highly uncertain, role in global radiative forcing. Commonly, ambient carbonaceous aerosols are internally mixed with secondary species such as nitrate, sulfate, and ammonium, which influences their optical properties, hygroscopicity, and atmospheric lifetime, thus impacting climate forcing. Aircraft-aerosol time-of-flight mass spectrometry (A-ATOFMS), which measures single-particle mixing state, was used to determine the fraction of organic and soot aerosols that are internally mixed and the variability of their mixing state in California during the Carbonaceous Aerosols and Radiative Effects Study (CARES) and the Research at the Nexus of Air Quality and Climate Change (CalNex) field campaigns in the late spring and early summer of 2010 . Nearly $88 \%$ of all A-ATOFMS measured particles (100-1000 $\mathrm{nm}$ in diameter) were internally mixed with secondary species, with $96 \%$ and $75 \%$ of particles internally mixed with nitrate and/or sulfate in southern and northern California, respectively. Even though atmospheric particle composition in both regions was primarily influenced by urban sources, the mixing state was found to vary greatly, with nitrate and soot being the dominant species in southern California, and sulfate and organic carbon in northern California. Furthermore, mixing state varied temporally in northern California, with soot becoming the prevalent particle type towards the end of the study as regional pollution levels increased. The results from these studies demonstrate that the majority of ambient carbonaceous particles in California are internally mixed and are heavily influenced by
\end{abstract}

secondary species that are most prevalent in the particular region. Based on these findings, considerations of regionally dominant sources and secondary species, as well as temporal variations of aerosol physical and optical properties, will be required to obtain more accurate predictions of the climate impacts of aerosol in California.

\section{Introduction}

Carbonaceous aerosols, comprised of soot and/or organic carbon (OC), affect climate directly through scattering and absorbing radiation and indirectly by influencing cloud formation, albedo, and lifetime (Ackerman et al., 2000; Poschl, 2005; Ramanathan et al., 2007; Rosenfeld and Givati, 2006). Soot, formed by incomplete combustion processes, is strongly absorbing and hence plays a key role in affecting climate through radiative forcing (Jacobson et al., 2000; Kanakidou et al., 2005; Ramanathan and Carmichael, 2008; Solomon et al., 2007). OC from vehicle, biogenic, and biomass burning emissions, as well as from secondary aerosol formation, can exhibit a wide range of optical properties which depend on the mixing state of particles (Hand and Malm, 2007; Jacobson et al., 2000; Kanakidou et al., 2005; Rudich et al., 2007). Soot and OC particles can form internal mixtures with one another as well as other secondary species, such as nitrate, sulfate, and ammonium, which strongly affects their optical and physical properties (Moffet et al., 2010; Prather et al., 2008; Spencer and Prather, 2006). 
Internal mixtures of $\mathrm{OC}$ and soot increase the absorption coefficient, leading to greater radiative forcing than predicted for either species alone (Schnaiter et al., 2005; Schwarz et al., 2008; Moffet and Prather, 2009). For example, Schnaiter et al. (2005) measured absorption amplification factors of 1.8 to 2.1 times higher for soot with coatings than without and similarly, Moffet and Prather (2009) found an absorption enhancement of 1.6 for soot particles coated with OC and secondary species over pure soot. Previous studies determined that water soluble coatings, such as sulfuric acid, lead to enhanced absorption over that of externally mixed particles (Khalizov et al., 2009; Naoe et al., 2009). In addition to absorption enhancement, coatings can alter particle hygroscopicity, which in turn affects the particle's optical and physical properties, as particles that are more hygroscopic will absorb more water, scatter radiation more efficiently, and have a higher potential to become cloud condensation nuclei (CCN) (Hand and Malm, 2007; Mochida et al., 2006; Wang et al., 2010). Laboratory and field studies show altered hygroscopicity for photochemically aged soot, due in part to the condensation of secondary species (Cappa et al., 2011; Furutani et al., 2008; Petters et al., 2006; Wang et al., 2010). For example, Petters et al. (2006) observed that as hydrophobic soot particles age they can become hydrophilic due to the addition of a sulfate or nitrate coating. Wang et al. (2010) determined that nitrate partitioned onto aerosols leads to increased CCN activity. Multiple studies have shown that particles can acquire coatings rapidly, sometimes in only a few hours, hence the amount of ambient particles existing as internal mixtures may represent a sizable fraction of total ambient aerosols (Jacobson, 2001; Riemer et al., 2010; Wang et al., 2010; Moffet and Prather, 2009). In addition, the aerosol optical and CCN activation properties may be sensitive to the degree of internal mixing even after 1 to 2 days (Zaveri et al., 2010).

Despite the importance of mixing state on particle optical and physical properties, atmospheric models generally represent the particle population as an external mixture (Koch et al., 2011). Chung and Seinfeld (2002) found the assumption of external mixing state may lead to as much as $\sim 0.4 \mathrm{~W} / \mathrm{m}^{2}$ underestimation in radiative forcing. Similarly, Jacobson estimated that global radiative forcing of soot increases by a factor of 2.9, when varied from an external to an internal mixture (Jacobson, 2001). Additionally, numerous studies have shown the sensitivity of climate to large aerosol perturbations (Leibensperger et al., 2012; Mickley et al., 2012; Kloster et al., 2010; Solomon et al., 2007). The potentially large effect on radiative forcing calculations due to mixing state necessitates empirical measurements to determine the extent of soot and non-absorbing species, such as OC, present in the atmosphere as internal or external mixtures.

Single particle mixing state is gradually becoming a more prevalent measurement in field studies (Brands et al., 2010; Gard et al., 1997; Murphy and Thomson, 1995; Zelenyuk and Imre, 2005). Ground-based measurements have shown the large variability in the mixing state of carbonaceous aerosols, even within just California (Chow et al., 1993; Chow et al., 2006). For example, Qin et al. (2012) found carbonaceous aerosols in Riverside, California were internally mixed with sulfate from photochemical processing during the summer, while nitrate was the dominant secondary species in the fall due to semivolatile partitioning of ammonium nitrate. In Bakersfield, California, carbonaceous aerosols were found to be internally mixed with ammonium, nitrate, and sulfate from partitioning of ammonium nitrate and ammonium sulfate (Whiteaker et al., 2002). An inherent limitation in ground-based measurements is their susceptibility to local sources. Aircraft sampling can cover large areas over short timescales, providing measurements that are indicative of an entire region and therefore may be more useful for evaluation of model predictions over large areas. Relatively few aircraft studies to date have measured single particle mixing state (Murphy et al., 2007; Pratt and Prather, 2010; Zelenyuk et al., 2010). Herein, in situ measurements of carbonaceous aerosol mixing state were determined using an aircraft-aerosol timeof-flight mass spectrometer (A-ATOFMS) over two major aircraft campaigns in California during the late spring and early summer of 2010 to elucidate (1) the fraction of carbonaceous particles that are internally and externally mixed and (2) differences in mixing state of carbonaceous particles between the two regions studied.

The Research at the Nexus of Air Quality and Climate Change (CalNex) campaign sampled aerosols over southern California, with the goal of understanding the role of particle composition on air quality and climate change (www.esrl. noaa.gov/csd/calnex/). A large area of northern California was characterized during the Carbonaceous Aerosols and Radiative Effects Study (CARES), a study that sought to follow the evolution of soot as particles are transported from fresh urban sources in Sacramento into the more remote Sierra Nevada foothills (campaign.arm.gov/cares/). These two studies conducted consecutively in May and June 2010 provide an assessment of particle mixing state throughout most of California.

\section{Experimental}

\subsection{Aircraft aerosol time-of-flight mass spectrometer}

A description of the A-ATOFMS is given in detail elsewhere (Pratt et al., 2009). In brief, the A-ATOFMS measures the vacuum aerodynamic diameter $\left(\mathrm{d}_{\mathrm{va}}\right)$ and chemical composition of single particles in real time for particles between $\sim 100-1000 \mathrm{~nm}$, with peak transmission between $200-700 \mathrm{~nm}$. Additional information on A-ATOFMS particle transmission within the aircraft is given in the supplementary. After passing a $\mathrm{Po}^{210}$ neutralizer and pressure controlled inlet (Bahreini et al., 2008), particles are focused through an aerodynamic lens (Liu et al., 1995a, b), where they are accelerated to their aerodynamic terminal velocity. 
The particles then pass through two continuous wave $532 \mathrm{~nm}$ lasers (JDSU) spaced $6.0 \mathrm{~cm}$ apart. The time difference between the scattering signals is used to calculate the velocity and size $\left(\mathrm{d}_{\mathrm{va}}\right)$ of the particle. The velocity is used to queue the firing of a $266 \mathrm{~nm}$ Q-switched Nd:YAG laser (Quantel), operating at $0.5-1.5 \mathrm{~mJ}$, for desorption and ionization of the particle. Dual polarity mass spectra are acquired after ions pass through a time-of-flight mass spectrometer (Tofwerk). The particle source is determined using positive spectra, while negative spectra provide information on the secondary species and chemical processing that the particle has undergone (Guazzotti et al., 2001; Noble and Prather, 1996; Prather et al., 2008).

Single-particle mass spectra were imported into Matlab (The MathWorks, Inc.) using the YAADA software toolkit (www.yaada.com). An adaptive resonance theorybased clustering algorithm (ART-2a, vigilance factor of 0.80 , learning rate of $0.5,20$ iterations, and regroup vigilance factor of 0.85) was used to group spectra into clusters based on similar mass spectral characteristics (Allen, 2002; Rebotier and Prather, 2007; Song et al., 1999). Data from each campaign were grouped and then analyzed separately using ART-2a. Greater than $95 \%$ of ART-2a analyzed particles were grouped into clusters which were further combined manually into 11 general particle types based on characteristic ion markers. Mass spectral peaks were identified according to the most probable ions at a given mass-to-charge $(\mathrm{m} / \mathrm{z})$ ratio. Particle source classifications were established based upon characteristic peaks identified in previous studies, however these labels do not reflect all of the species present in a particle type, i.e. the presence of secondary species such as sulfate or nitrate. Calculated standard errors of number fractions were small, $<1 \%$, hence were not included in this discussion.

\subsection{CalNex - Southern California}

Measurements were taken onboard the Center for Interdisciplinary Remotely-Piloted Aircraft Studies (CIRPAS) Twin Otter. Flight operations were based out of Ontario, CA through the Guardian Jet center, a part of the Los Angeles (LA)/Ontario international airport. There were nine flights during the study period of 5 May 2010-18 May 2010, with each flight lasting $\sim 4 \mathrm{~h}$ with a usual start time of $\sim 11$ a.m. local time (PDT). All flight tracks are shown in Fig. 1 and flight dates can be found in Supplement Table 1. Flights were focused in the LA basin, often making multiple circuits over the area. Results from the CalNex campaign are referred to as southern California hereafter. Particle concentrations and size from 100-3000 nm were measured by a Passive Cavity Aerosol Spectrometer Probe (PCASP), and two Condensation Nuclei Counters (CPC, TSI models 3010 and 3025), detecting particles down to 10 and $3 \mathrm{~nm}$ respectively. The AATOFMS collected data for 8 out of 9 flights, measuring the

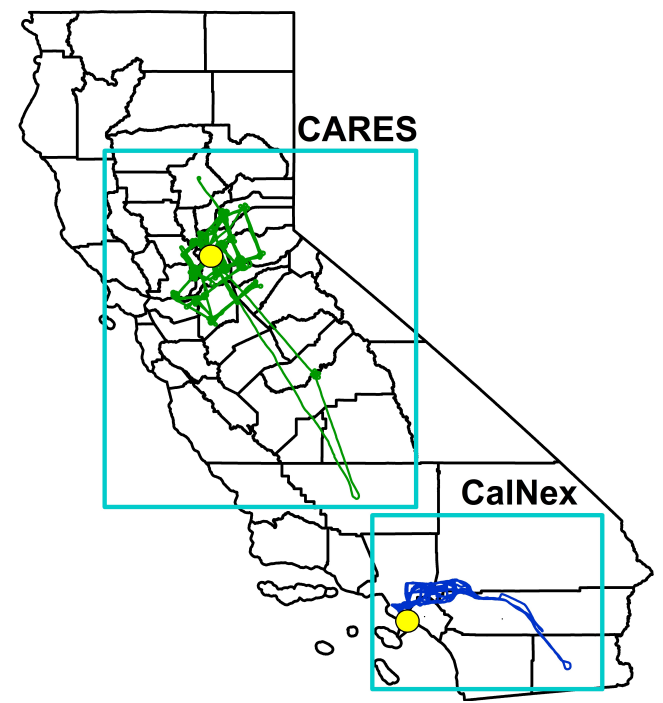

Fig. 1. Operational areas for CARES and CalNex. All flight paths are overlaid on each other. Yellow dots represent Sacramento (CARES) and Los Angeles (CalNex).

chemical composition and size of 75969 particles during this study.

\subsection{CARES - Northern California}

Flights were operated out of the McClellan airfield in Sacramento, CA from 2-28 June 2010 onboard the Department of Energy Gulfstream-1. This study focused on the surrounding urban Sacramento area and Sierra Nevada foothills, thus results from this campaign are interchangeably referred to as northern California. Usually each sampling day consisted of a flight in the morning, $\sim 8$ a.m. local, and in the afternoon, $\sim 2$ p.m. local, with most flights lasting $\sim 4$ h. Flight dates are given in Supplement Table 1, while the flight paths for all 22 flights during the study are shown in Fig. 1. More details on the campaign and instrumentation aboard the aircraft can be found elsewhere (Zaveri et al., 2012). Gas-phase concentrations of $\mathrm{SO}_{2}$ and $\mathrm{NO}_{\mathrm{x}}$, as well as other species were measured in flight. Total condensation nuclei $(\mathrm{CN})$ concentrations were measured using the same CPC models used in the CalNex campaign (TSI models 3010 and 3025). Number concentration and size for particles with sizes from 55-1000 nm were detected using an Ultra-High Sensitivity Aerosol Spectrometer (UHSAS) probe (Droplet Measurement Technologies). For direct comparisons of gasphase species and particle concentrations between CalNex and CARES, representative average concentrations were calculated using data from the California Air Resources Board (CARB, http://www.arb.ca.gov) ground based measurements from North Main Street in LA and from Del Paso Manor in Sacramento to represent CalNex and CARES, respectively. The A-ATOFMS was on-line for 20 of 22 total flights, chemically analyzing 60230 particles. 

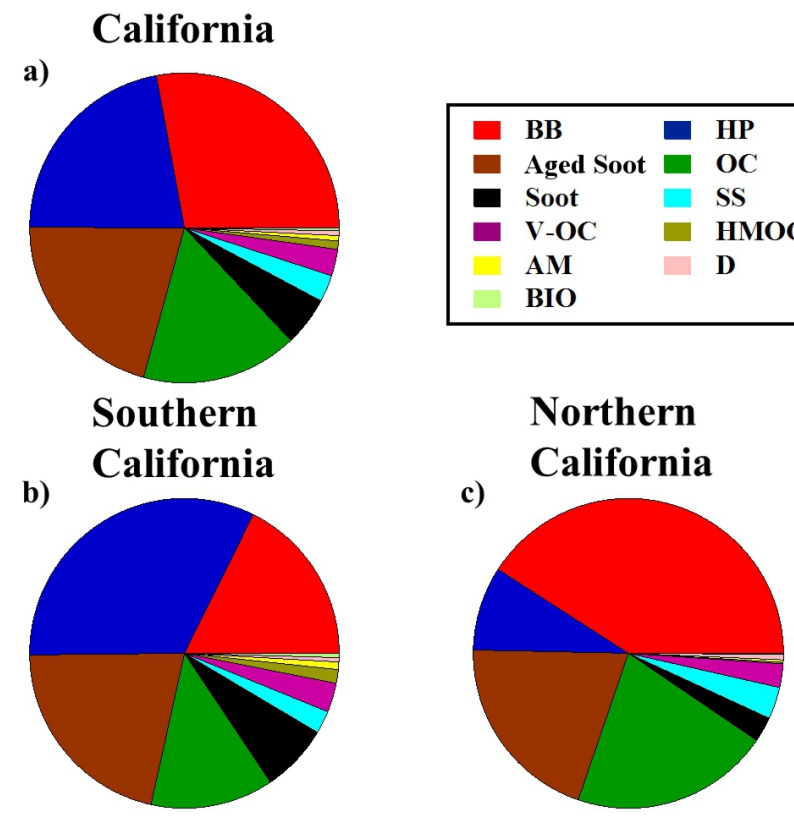

Fig. 2. Number fractions of A-ATOFMS particle sources, determined by the most dominant ions in A-ATOFMS mass spectra, for California (a), southern California (b), and northern California (c).

\section{Results}

\subsection{Particle sources throughout California}

As shown in Fig. 2a, predominant particle sources by number fraction in the boundary/residual layers of both campaigns were identified as biomass burning (BB), highly processed (HP), soot mixed with OC (Aged Soot), OC, and soot, which represented $28,22,21,16$, and $5 \%$ of total particle counts measured by the A-ATOFMS in both studies, respectively. BB originated from agricultural and residential burning, which is most prevalent in the rural regions of northern California. These spectra are characterized by an intense potassium peak at mass/charge $(\mathrm{m} / \mathrm{z})^{39} \mathrm{~K}^{+}$(Fig. 3a) in addition to less intense $\mathrm{OC}$ and soot peaks at $m / z^{12} \mathrm{C}^{+},{ }^{24} \mathrm{C}_{2}^{+}$, ${ }^{27} \mathrm{C}_{2} \mathrm{H}_{3}^{+} / \mathrm{CHN}^{+},{ }^{29} \mathrm{C}_{2} \mathrm{H}_{5}^{+},{ }^{36} \mathrm{C}_{3}^{+}$, and ${ }^{43} \mathrm{C}_{2} \mathrm{H}_{3} \mathrm{O}^{+} / \mathrm{CHNO}^{+}$ (Bi et al., 2011; Guazzotti et al., 2001; Hudson et al., 2004; Silva et al., 1999). HP are particles for which only negative ion spectra were acquired. Since the core, which is shown in the positive ion spectra, was not obtained, the source of these particles cannot be identified, but they are hypothesized to be carbonaceous particles that have undergone extensive processing. Size distributions of these particles are nearly identical to those of Aged Soot particles $\left(R^{2}=0.98\right)$ and to a lesser extent BB and OC particles $\left(R^{2}=0.93\right.$ and 0.89 , respectively), lending support to the hypothesis that they are most likely heavily coated soot particles. Thus, these particles will be included as carbonaceous aerosol in subsequent discussions.
Aged Soot, formed primarily through fossil fuel combustion and subsequent coagulation with or condensation of semivolatile organic species, has intense elemental carbon $\mathrm{C}_{n}^{+}$peaks $\left({ }^{12} \mathrm{C}^{+},{ }^{24} \mathrm{C}_{2}^{+},{ }^{48} \mathrm{C}_{3}^{+}\right)$with weaker OC peaks, $m / z{ }^{27} \mathrm{C}_{2} \mathrm{H}_{3}^{+},{ }^{29} \mathrm{C}_{2} \mathrm{H}_{5}^{+},{ }^{37} \mathrm{C}_{3} \mathrm{H}^{+},{ }^{39} \mathrm{C}_{3} \mathrm{H}_{3}^{+} / \mathrm{K}^{+},{ }^{43} \mathrm{C}_{2} \mathrm{H}_{3} \mathrm{O}^{+}$ (Spencer and Prather, 2006; Moffet and Prather, 2009) (Fig. 3b). Peaks at $m / z{ }^{27} \mathrm{C}_{2} \mathrm{H}_{3}^{+} / \mathrm{CHN}^{+},{ }^{29} \mathrm{C}_{2} \mathrm{H}_{5}^{+},{ }^{37} \mathrm{C}_{3} \mathrm{H}^{+}$, ${ }^{39} \mathrm{C}_{3} \mathrm{H}_{3}^{+} / \mathrm{K}^{+}$, and ${ }^{43} \mathrm{C}_{2} \mathrm{H}_{3} \mathrm{O}^{+} / \mathrm{CHNO}^{+}$are indicative of $\mathrm{OC}$ species from vehicle and biogenic emissions (Fig. 3c). Peaks at $m / z{ }^{50} \mathrm{C}_{4} \mathrm{H}_{2} / \mathrm{C}_{3} \mathrm{~N}^{+},{ }^{59} \mathrm{C}_{3} \mathrm{H}_{9} \mathrm{~N}^{+}$, and peaks at $\mathrm{m} / \mathrm{z}^{12} \mathrm{C}^{+}$, ${ }^{24} \mathrm{C}_{2}^{+},{ }^{48} \mathrm{C}_{3}^{+}$, similar to soot, were occasionally also seen on OC particles but at significantly lower relative intensities (Spencer and Prather, 2006). Figure 3d shows soot spectra which consist of almost entirely elemental carbon $\mathrm{C}_{n}^{+}$peaks out to the high mass range, i.e. $m / z{ }^{12} \mathrm{C}^{+},{ }^{24} \mathrm{C}_{2}^{+} \ldots{ }^{180} \mathrm{C}_{15}^{+}$, and $\mathrm{C}_{n}^{-}$peaks from $m / z{ }^{12} \mathrm{C}^{-},{ }^{24} \mathrm{C}_{2}^{-} \ldots{ }^{72} \mathrm{C}_{6}^{-}$in negative spectra. As this particle type does not typically contain secondary species it is thought to be relatively fresh. Other carbonaceous and non-carbonaceous particle types like vanadium mixed with OC (V-OC) (Ault et al., 2009), high mass OC (HMOC) (Silva and Prather, 2000), amine (AM) (Angelino et al., 2001; Pratt and Prather, 2010; Sorooshian et al., 2008), biological (BIO) (Fergenson et al., 2004; Pratt and Prather, 2010; Russell, 2009), dust (D) (Pratt and Prather, 2010; Silva and Prather, 2000), and sea salt (SS) (Gard et al., 1998) each represented $<3 \%$ of total aerosol and are described in detail in the supporting information. Most particle types did not have a strong dependence on size (Supplement Fig. 1), with the one exception of SS particles which had a clear dependence towards larger $(>600 \mathrm{~nm})$ sizes. A more detailed discussion of the chemical dependence on particle size is given in the Supplement. Negative ion spectra were absent in $13 \%$ of particles for both studies, with the majority of these occurring during the CARES (24\%) rather than the CalNex campaign (4\%). This is dependent on both instrument sensitivities and the amount of processing the particle has undergone. A more detailed discussion of only positive ion spectra is given in the supporting information.

\subsection{Particulate secondary species in California}

For particles with the same base chemical signature (i.e. biomass, soot, OC, etc.), relative peak areas (RPA) qualitatively reflect the amount of a species on a particle in relation to other species (Bhave et al., 2002; Gross et al., 2000; Prather et al., 2008). Previous studies in California have shown that the presence of ammonium nitrate (Sorooshian et al., 2008; Langridge et al., 2012) and ammonium sulfate (Qin et al., 2012) can influence single particle mixing state. During this study, partitioning of methanesulfonic acid (MSA) and organosulfate (OS) to particles was likely to occur in the vicinity of marine and heavily forested areas where MSA and OS, respectively, originate (Gaston et al., 2010; Hatch et al., 2011). To examine the mixing state of particles with biogenic, marine, and anthropogenic species, single particle 

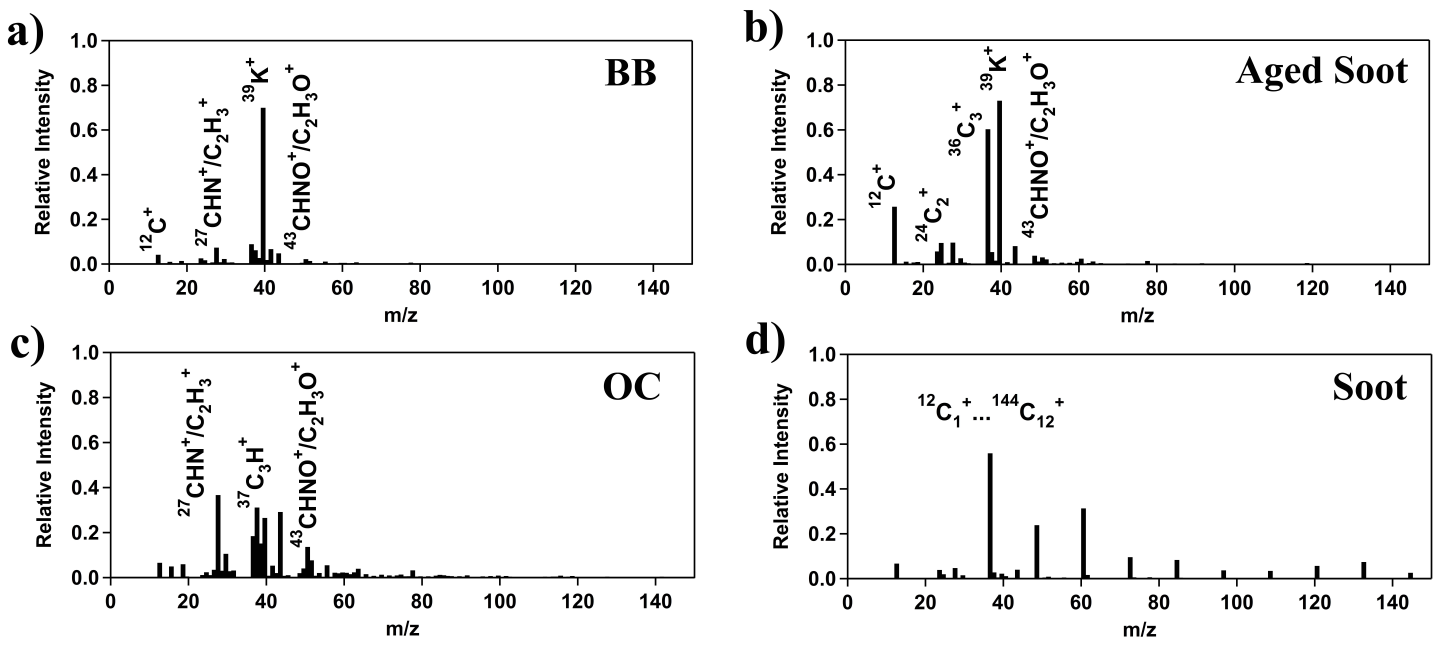

Fig. 3. A-ATOFMS particle types for the main carbonaceous species, (a) biomass burning (BB), (b) soot mixed with organic carbon (Aged Soot), (c) organic carbon (OC), and (d) soot. A wide array of negative ions, indicative of secondary species, were observed on these particle sources, hence are not shown here, but common negative ions are discussed in text and can be found in Fig. 10.

mixing state was examined by identifying peaks of ammonium $\left({ }^{18} \mathrm{NH}_{4}^{+}\right)$, sulfate $\left({ }^{97} \mathrm{HSO}_{4}^{-},{ }^{195} \mathrm{H}_{2} \mathrm{SO}_{4} \mathrm{HSO}_{4}^{-}\right)$, nitrate $\left({ }^{46} \mathrm{NO}_{2}^{-},{ }^{62} \mathrm{NO}_{3}^{-},{ }^{125} \mathrm{H}\left(\mathrm{NO}_{3}\right)_{2}^{-}\right)$(Silva and Prather, 2000), MSA $\left({ }^{95} \mathrm{CH}_{3} \mathrm{SO}_{3}^{-}\right.$) (Gaston et al., 2010), and/or OS (derived from glycolic acid (m/z -155), 2-methylglyceric acid $(\mathrm{m} / \mathrm{z}$ $-199)$, and isoprene epoxydiol $(m / z-215)$ ) (Hatch et al., 2011). Other secondary species were investigated, but no significant trends were seen. A particle is considered to contain these species if the RPA for $m / z$ ratios indicative of those species exceeds $0.5 \%$ of the mass spectrum. For example, a particle contains sulfate if the RPA at $m / z-97$ or -195 is greater than $0.5 \%$ of the ions in the entire mass spectrum.

Most particles in California were found to be internally mixed with secondary species, with nearly $88 \%$ of particles by number containing sulfate, nitrate, MSA, OS, or ammonium individually or internally mixed together. Commonly, particles contained sulfate ( $82 \%$ ) or nitrate $(82 \%)$, and $76 \%$ of particles had both, but, as discussed below, the magnitude of these species varied greatly between southern and northern California.

\subsection{Southern California aerosol mixing state}

In the LA basin, frequently capped by a temperature inversion, a prevailing sea breeze transports air to the east toward the outflow pathways for the basin. Most Twin Otter flights in southern California were carried out at low altitudes, $<700 \mathrm{~m}$, sampling within the boundary layer. The number fractions of the main carbonaceous aerosol types from southern California differed greatly from those in California as a whole, as shown in Fig. 2b. Particles were generally highly aged, as seen by the high fraction of HP aerosols in the region $(33 \%)$. Particles are often entrained within the basin, where they can undergo significant atmospheric pro- cessing (Schultz and Warner, 1982; Ulrickson and Mass, 1990). Aged Soot, BB, OC, and soot were the other main particle types present, comprising $21,18,13$, and $7 \%$ of A-ATOFMS total particle counts in southern California. VOC, AM, HMOC, and BIO represented 3.0, 0.8, 1.4, and $0.5 \%$ of total particles, respectively. Excluding HP particles, nearly $96 \%$ of submicron particles measured by the A-ATOFMS in southern California contained carbonaceous material. Though some variability was seen flight-to-flight during CalNex, generally number fractions for the main particle types did not deviate greatly from the number fractions reported above. Representative soot $\left({ }^{36} \mathrm{C}_{3}^{+},{ }^{48} \mathrm{C}_{4}^{+},{ }^{60} \mathrm{C}_{5}^{+}\right)$and OC $\left({ }^{27} \mathrm{C}_{2} \mathrm{H}_{3}^{+},{ }^{29} \mathrm{C}_{2} \mathrm{H}_{5}^{+},{ }^{37} \mathrm{C}_{3} \mathrm{H}^{+},{ }^{43} \mathrm{C}_{2} \mathrm{H}_{3} \mathrm{O}^{+}\right)$ions $>0.5 \%$ of the mass spectrum were present in $62 \%$ and $63 \%$ of total particles, respectively (Fig. 4, left panel) (Spencer and Prather, 2006). Normally soot is emitted at sizes below the detection limit of the instrument $(100 \mathrm{~nm})$. The fact that particles with intense soot peaks were seen indicates that soot particles had grown into the A-ATOFMS size range. Secondary species, such as nitrate, sulfate, and OC, contribute to this growth, but the extent each component plays in particle growth is unknown. OC RPA cannot be compared directly to sulfate and nitrate RPA as their ion formation mechanisms are different. However, OC and soot RPAs can be compared to determine the relative amount of $\mathrm{OC}$ mass on a particle. If the magnitude of OC peaks is low, then other species must have contributed to the growth of soot into larger sizes. To elucidate the magnitude of soot with $\mathrm{OC}$ in the same particle, a peak ion ratio of OC:soot was calculated by dividing the total RPA for each species by the other. These ratios form a distribution of values that represents all of the variance in magnitude of these species on particles ranging from pure OC to pure soot. Since these ratios are calculated for a single particle, they are not dependent on laser fluence or matrix effects, 


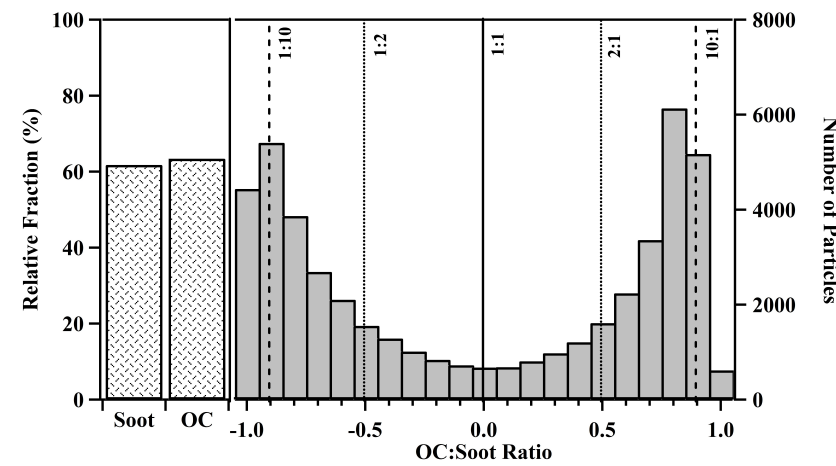

Fig. 4. Fraction of particles containing soot and OC RPA $>0.5 \%$ in southern California (left panel). Single particle OC:soot peak ion ratio distributions are shown in (right panel). Values $<0$ indicate more soot than OC on single particles and values $>0$ indicate more OC than soot. Ratios representing 1:1, 2:1, and 10:1 are shown by solid, dotted, and dashed lines, respectively.

assuming that the entire particle is completely ablated and that matrix effects suppress the selected ions equally (Morrical et al., 1998; Wenzel and Prather, 2004). It should be noted that OC particles could contain a soot core that was not ablated fully, which would affect these calculations, and that HP particles were not included in this analysis since they did not contain positive ions (Steele et al., 2003; Morrical et al., 1998; Pratt and Prather, 2009).

The OC:soot ion ratio distribution for particles in southern California is shown in Fig. 4, right panel. For visual clarity, the OC:soot ratio has been normalized so that ratios $<1$ will approach -1 as it proceeds to $-\infty$ (i.e. soot without OC) and a ratio $>1$ will approach 1 as the ratio proceeds to $+\infty$ (i.e. OC without soot). Further details on these calculations can be found in the supporting information. It should be emphasized that as ratios approach -1 or 1 , they are exponentially increasing, while nearing zero the RPA of each species is essentially the same. This results in a broader range of ratios for bins near -1 or 1 , while near 0 bins include a smaller range of ratios. As expected, a distribution of OC:soot ratios exists, demonstrating the variability in mixing state observed in southern California. As shown in Fig. 4, right panel, a nearly equal number of particles have ratios above and below 0 , although pure soot has nearly seven times as many particles as pure OC. On days when OC dominates the mass spectra, influences from $\mathrm{BB}$ were significant, which is expected since BB is composed of nearly $62 \%$ OC by mass for smoldering fires (Reid et al., 2005). Soot likely originated from fossil fuel vehicle emissions in the LA basin (Ying and Kleeman, 2006).

Most particles in southern California had been processed to some degree, as indicated by $\sim 96 \%$ of particles producing negative ion spectra with secondary species. Similarly, Metcalf et al. (2012) found that most soot particles were present with coatings of varying thicknesses during the Cal-

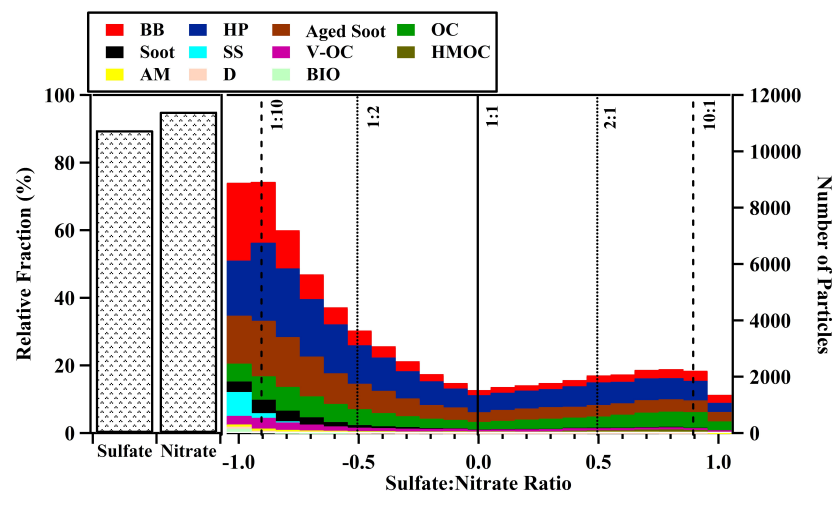

Fig. 5. Fraction of particles containing sulfate and nitrate RPA $>0.5 \%$ in southern California (left panel). Sulfate:nitrate ion ratio distributions are shown in (right panel). Values $<0$ indicate more nitrate than sulfate and values $>0$ indicate more sulfate than nitrate. Ratios representing 1:1, 2:1, and 10:1 are shown by solid, dotted, and dashed lines respectively.

Nex study. Nitrate appeared on $95 \%$ of particles by number, and $90 \%$ of particles contained sulfate peaks (Fig. 5, left panel). Ratios of sulfate:nitrate RPAs, calculated in the same manner as OC:soot ratios, for every particle (including HP) are shown in Fig. 5, right panel. Most particles contain more nitrate than sulfate, but still a significant number of particles contain more sulfate than nitrate. This largely corroborates reported findings from other measurements during CalNex (Langridge et al., 2012; Metcalf et al., 2012). To see if there is preferential partitioning of nitrate or sulfate to any particular source, the ion ratio distribution in Fig. 5, right panel was split into particle sources. Most particle sources have very similar ion ratio distributions that cover a wide range of sulfate:nitrate values, indicating that nitrate and sulfate partitioned to particles regardless of the original source/core. SS and $\mathrm{V}-\mathrm{OC}$ are the only exception, as both of these types are present with ion ratio distributions exclusively favoring nitrate. Nitrate is known to heterogeneously replace chloride on SS particles as they age, which may explain the preference of nitrate to SS observed in peak ratios (Gard et al., 1998). Ault et al. (2010) measured V-OC particles near to the emission source and hypothesized that vanadium acted as a catalyst to produce sulfate from $\mathrm{SO}_{2}$. In the present work particles were measured farther from the source and are processed to a higher degree such that nitrate might have replaced sulfate on those particles. This analysis demonstrates that ion ratio distributions may be used to identify different processing mechanisms when preferential partitioning of species to distinct types is observed.

Large nitrate fractions can be attributed to high $\mathrm{NO}_{\mathrm{x}}$ concentrations over Los Angeles, an average of $32 \mathrm{ppb}$ for the study period (CARB). In addition, ammonium nitrate originates from animal husbandries surrounding the Los Angeles area near Chino, which have been shown to be a large source of ammonia in the region (Kleeman and Cass, 1998; Singh et 
al., 2002; Sorooshian et al., 2008; Ying and Kleeman, 2006). Ammonium was found to be present in $37 \%$ of total particles, so the high nitrate seen in CalNex could in part be due to the presence of ammonium nitrate. Nearly $98 \%$ of particles internally mixed with sulfate were also mixed with nitrate, whereas only $93 \%$ of particles internally mixed with nitrate were mixed with sulfate in southern California. MSA was present on $52 \%$ of total particles in southern California, indicating that sulfate originating from marine sources was prevalent in the region, as expected due to the close proximity of LA to the ocean $(\sim 30 \mathrm{~km})$ (Ying and Kleeman, 2006). A small fraction of particles contained organosulfate peaks ( $28 \%)$, likely due to smaller biogenic influence in the LA basin.

\subsection{Northern California aerosol mixing state}

The Sacramento region is characterized by consistent southwesterly flow that carries air into the Sierra Nevada foothills during the day and recirculates the air back towards Sacramento at night, forming a residual layer of aged air the next day (Zaremba and Carroll, 1999; Fast et al., 2012). Most flights sampled at low altitudes, $<700 \mathrm{~m}$, in either the boundary layer or residual layer. Number fractions of particles in northern California are shown in Fig. 2c. Unlike in southern California, BB represented a more significant fraction of particles ( $41 \%$ by number), due to increased residential and agricultural burning in the rural regions in northern California. HP particles did not represent as large a fraction in northern California, comprising only $9 \%$ of particles versus $33 \%$ in Southern California. Furthermore, only $76 \%$ of particles contained negative ion spectra, suggesting that particles in northern California had not undergone as much processing as in southern California. Often the lack of negative ion spectra is attributed to the presence of water (Neubauer et al., 1998, 1997), however relative humidity (RH) was lower on average during the CARES study $(39 \pm 14 \%)$ compared to CalNex $(49 \pm 30 \%)$, hence the potential impact of water on suppressing negative ion spectra should be less relative to CalNex.

As was observed in southern California, OC and Aged Soot comprised a significant fraction of total aerosol in northern California, $21 \%$ and $20 \%$, respectively. Pure soot was present at lower number fractions (3\%) than in southern California (7\%), though a better representation of soot and OC content can be found through peak areas and peak area ratios. Significant soot and OC peaks were found in $84 \%$ and $87 \%$ of total particles, respectively (Fig. 6, left panel). The single particle ion ratio distribution of OC:soot (Fig. 6, right panel), which are directly comparable between studies, indicates that OC was more significant in northern California as compared to southern California, with nearly $64 \%$ of ratios $>1$, hence having greater relative OC content. This fraction is significantly higher than that in southern California (48\%) and is likely due to the heavily forested Sierra Nevada foothills ly-

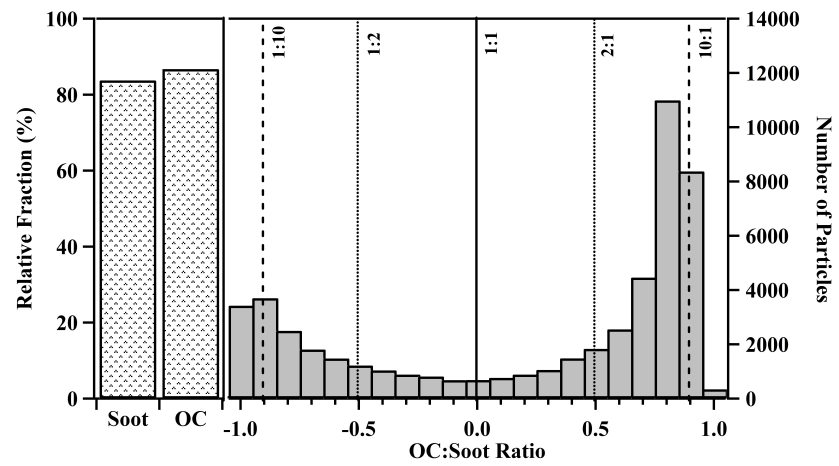

Fig. 6. Fraction of particles containing soot and OC RPA $>0.5 \%$ in northern California (left panel). OC:soot ion ratio distributions are shown in (right panel). Values $<0$ indicate more soot than OC and values $>0$ indicate more $\mathrm{OC}$ than soot. Ratios representing $1: 1,2: 1$, and 10:1 are shown by solid, dotted, and dashed lines respectively.

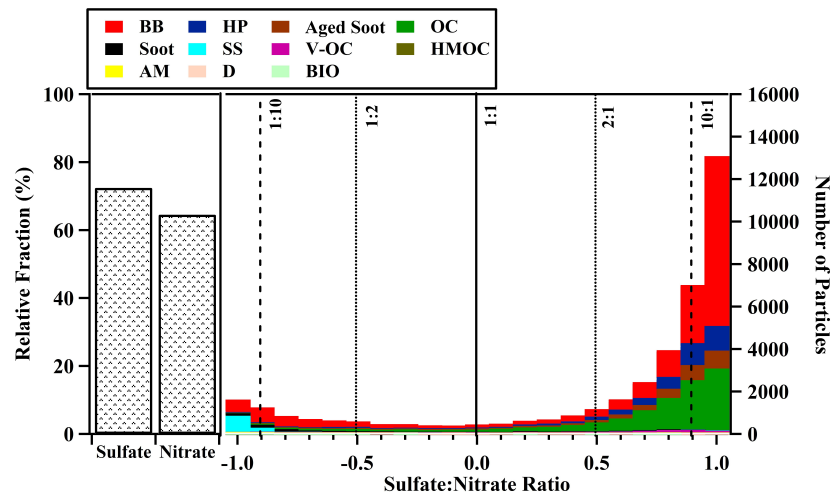

Fig. 7. Fraction of particles containing sulfate and nitrate RPA $>0.5 \%$ in northern California (left panel). Sulfate:nitrate ion ratio distributions are shown in (right panel). Values $<0$ indicate more nitrate than sulfate and values $>0$ indicate more sulfate than nitrate. Ratios representing 1:1, 2:1, and 10:1 are shown by solid, dotted, and dashed lines respectively.

ing to the northeast of Sacramento, which act as a source of biogenically derived OC particles.

In contrast to southern California, most particles in northern California were primarily mixed with sulfate rather than with nitrate. Sulfate peaks were internally mixed with $72 \%$ of particles in northern California (Fig. 7, left panel). Of those particles containing sulfate, $59 \%$ contained nitrate, though sulfate markers were usually many times more prominent than nitrate markers on the same particle. Few particles contained only nitrate $(\sim 3 \%)$, while $13 \%$ of particles comprised only sulfate. Figure 7, right panel shows the sulfate:nitrate ion ratio distribution for particles containing sulfate or nitrate in northern California. $80 \%$ of particles contained more sulfate than nitrate and $\sim 51 \%$ of those particles had a ratio $>10: 1$. Similar to southern California, ratios covered a wide range of values, though in northern California ion ratio distributions did not indicate preferential partitioning of 
sulfate or nitrate to any particle type, with the exception of SS which was present with high ratios of nitrate, as in southern California. The decreased prevalence of nitrate in northern California can be attributed to lower $\mathrm{NO}_{\mathrm{x}}$ emissions in northern California as compared to southern California, with $1 \mathrm{~h}$ averages of 4 and $32 \mathrm{ppb}$, respectively, from measurements at ground sites in Sacramento and LA (CARB). Ammonium was present in amounts similar to those in southern California, representing nearly $42 \%$ of total particles, suggesting the presence of ammonium sulfate. Recently published findings from AMS measurements at the T1 rural ground site during CARES, near the Sierra Nevada foothills, determined that much of particulate sulfate was indeed present as ammonium sulfate (Setyan et al., 2012).

One can gain insight into the source of sulfur species by examining the presence of MSA (originating from marine air) and OS (originating from biogenic aerosol) on single particles. While OS and MSA peaks were detected on $35 \%$ and $50 \%$ of particles, respectively, sulfate was present on $72 \%$ of particles, and usually exhibited higher peak intensities. Fast et al. (2012) hypothesized that a significant fraction of $\mathrm{SO}_{2}$ present in the CARES region originates from the oil refineries in the Carquinez Strait, near San Francisco, as no substantial sources of $\mathrm{SO}_{2}$ exist in the Sacramento area. While anthropogenic $\mathrm{SO}_{2}$ from this source is likely responsible for the high sulfate present on single particles, some days were observed to have high fractions of particles containing OS and MSA, indicating significant contributions from natural sources. For example, on 14 June, nearly $70 \%$ of the particles contained OS, and on 3 June, $72 \%$ of particles contained MSA. These elevated fractions occurred toward the beginning of the study and, as will be discussed in the following section, particle composition exhibited significant temporal variability during the CARES study.

\subsection{Temporal differences in northern California aerosol: NoCal-1 and NoCal-2}

As mentioned previously, the particle sources during CalNex were quite stable over the duration of the study. However, a noticeable shift in particle composition, particulate mass, and meteorology occurred during CARES after 21 June (Supplement Fig. 2). The sources and processes contributing to these two periods were quite different. To examine these differences in detail, the CARES study was separated into two periods, Northern California-1 (NoCal-1) and Northern California-2 (NoCal-2), representing fights from 219 June 2010 and 21-28 June 2010, respectively. NoCal-1 was relatively clean compared to NoCal-2, which was influenced more by local sources, evidenced by an increase of particulate matter $<2.5 \mu \mathrm{m}\left(\mathrm{PM}_{2.5}\right)$ by $12 \%$ measured at the CARB Del Paso Manor site, from 5.7 to $8.0 \mu \mathrm{g} \mathrm{m}^{-3}$ for NoCal-1 and NoCal-2, respectively. Mean gas-phase concentrations of $\mathrm{SO}_{2}$ and $\mathrm{NO}_{\mathrm{x}}$ measured in flight increased as well from NoCal-1 to NoCal- 2 by $23 \%$ and $25 \%$, respec-

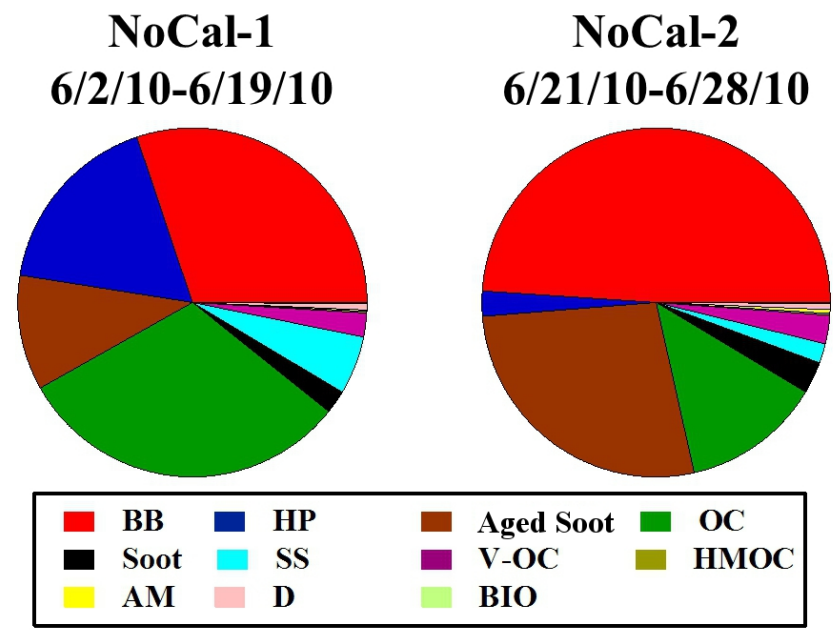

Fig. 8. Number fractions of A-ATOFMS particle types for two periods in the CARES campaign, NoCal-1 and NoCal-2.

tively. Similarly, Fast el al. (2012) described increased $\mathrm{O}_{3}$ and weaker winds during the same approximate period as NoCal-2 (Fast et al., 2012). Mean UF-CPC particle concentrations decreased by $\sim 32 \%$, while larger particles measured by the UHSAS, which are detected more efficiently by the AATOFMS, increased in number by $56 \%$. Correspondingly, A-ATOFMS average particle counts per flight increased between the first and second half of CARES by $71 \%$.

As shown in Supplement Fig. 2, the relative fractions of particle types for each flight during CARES change after 19 June 2010, which coincides with an increase in average $\mathrm{PM}_{2.5}$ mass. NoCal-2 exhibited significantly higher fractions of Aged Soot and BB than in NoCal-1 (Fig. 8), an increase of 17 and $19 \%$ by number, respectively, and a corresponding decrease in the fraction of OC, suggesting less biogenic influence in the region. Interestingly, particulate chemistry in NoCal-2 and southern California was remarkably similar, with the exception of the relative magnitudes of sulfate and nitrate on particles. Since it is unlikely that a new source of soot emerged from Sacramento during NoCal-2, the increased detection of soot-containing particles resulted from the growth of preexisting soot particles through condensation of organic vapors and $\mathrm{SO}_{2}$, manifested as more Aged Soot mixed with sulfate in A-ATOFMS data. The number fractions of particles containing peaks of soot, $75 \%$ and $90 \%$, and OC, $78 \%$ and $93 \%$, for NoCal- 1 and NoCal-2 respectively, were similar in magnitude during both periods but increase in NoCal-2 (Fig. 9, left panel). However, a comparison of the OC:soot ion ratio distributions from NoCal-1 to NoCal-2 indicates a shift in the OC:soot ion ratio distribution towards a nearly identical distribution as that observed in southern California (Fig. 4, right panel), where nearly half of the ion ratio distribution favored soot (Fig. 9, right panel). In contrast, the OC:soot ion ratio distribution for NoCal-1 (Fig. 9, right panel) was dominated by OC. Higher UF-CPC 


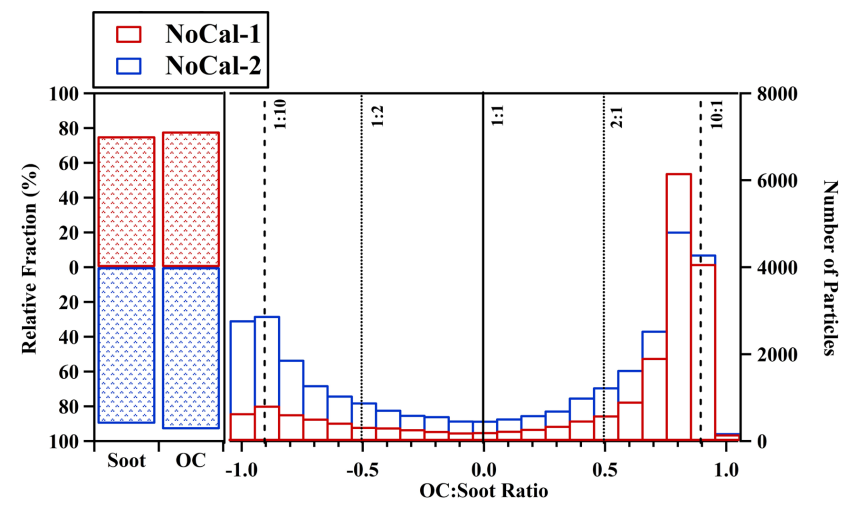

Fig. 9. Fraction of particles containing soot and OC with RPA $>0.5 \%$ in NoCal-1 (blue) and NoCal-2 (red) (left panel). OC:soot ion ratio distribution are shown in (right panel). Values $<0$ indicate more soot than OC and values $>0$ indicate more OC than soot. Ratios representing 1:1, 2:1, and 10:1 are shown by solid, dotted, and dashed lines respectively.

concentrations during NoCal-1 indicate that soot particles were present over the urban Sacramento region during this first period, but at sizes below the A-ATOFMS detection limit $(<100 \mathrm{~nm})$. During NoCal-1, OC content can primarily be attributed to biogenically derived $\mathrm{OC}$ from the surrounding forested regions, whereas during NoCal-2 OC primarily existed as a coating on a soot core similar to observations in southern California. With higher $\mathrm{NO}_{\mathrm{x}}$ emissions, soot particles in LA exhibit higher number fractions mixed with nitrate observed by the A-ATOFMS. Similarly to LA, higher $\mathrm{SO}_{2}$ and $\mathrm{NO}_{\mathrm{x}}$ concentrations during NoCal-2 led to the faster growth of soot, and an increase in the fraction of ratios favoring soot measured by the A-ATOFMS.

Sulfate:nitrate ion ratio distributions were relatively unchanged between NoCal-1 and NoCal-2 (Supplement Fig. 3). However, the fractions of MSA and OS on total particles decreased significantly from NoCal-1 to NoCal-2, from $66 \%$ to $38 \%$ and $49 \%$ to $24 \%$ for MSA and OS, respectively. One concludes that during NoCal-1 particulate sulfate was heavily influenced by natural sources, while during NoCal-2 anthropogenic sources dominated.

\subsection{Comparison between northern and southern California aerosol mixing state}

The most striking difference between mixing states in northern and southern California is the greater magnitude of single particles mixed with sulfate in the north and nitrate in the south. Figure 10 shows the difference in RPA from averaged BB, OC, and Aged Soot mass spectra obtained in southern (top) and northern (bottom) California. Positive intensities indicate peaks that were more prevalent in southern California while negative intensities indicate prevalence in northern California. All three particle types clearly indicate more intense sulfate peaks in the north and more intense nitrate

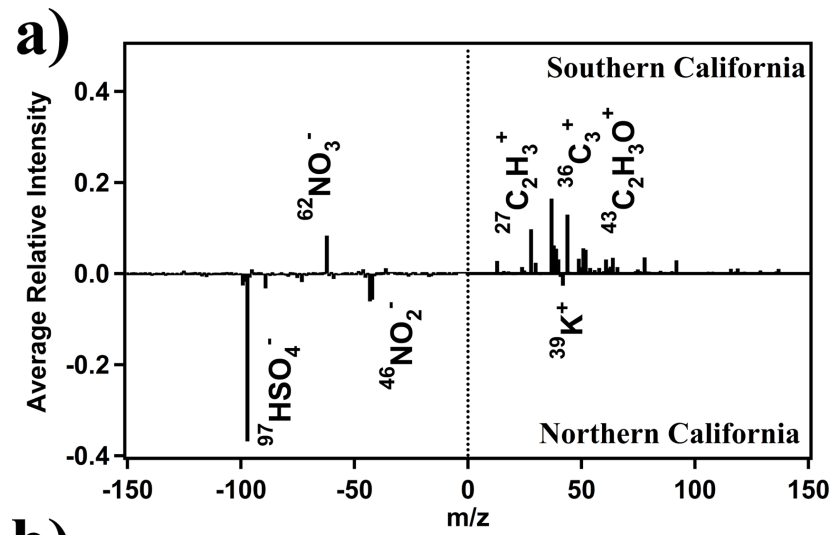

b)
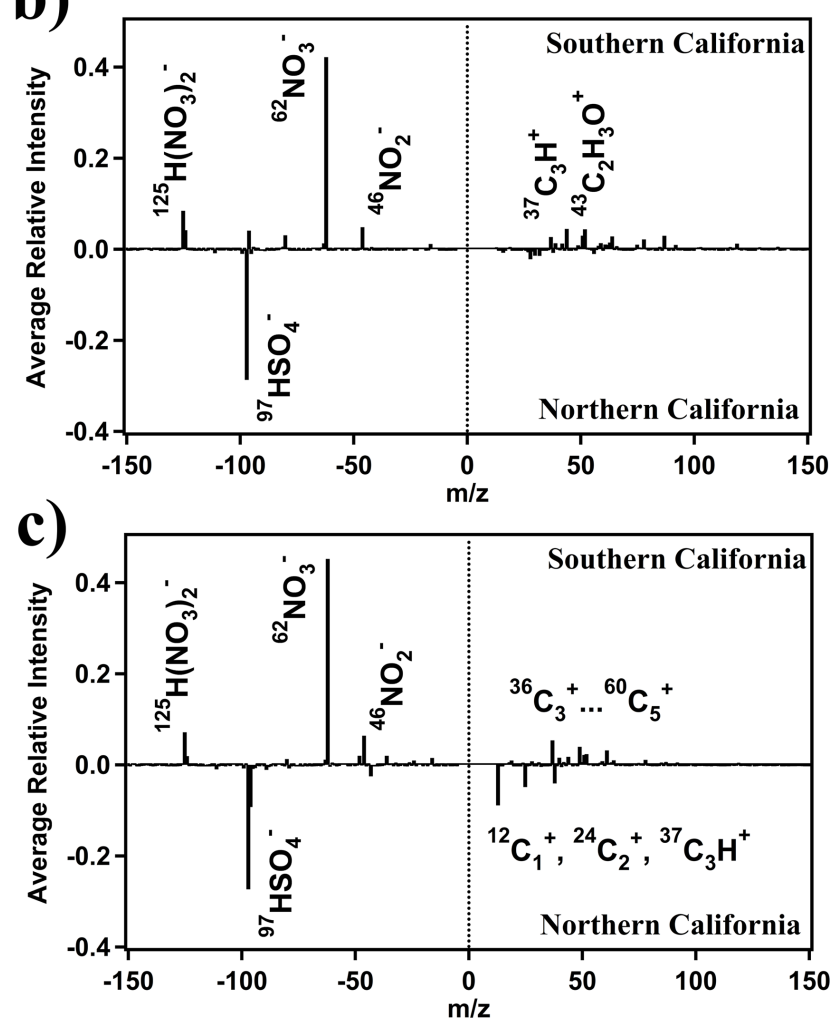

Fig. 10. Spectral difference plots of (a) BB, (b) OC, and (c) Aged Soot particles from southern (top) and northern (bottom) California. Secondary species show the greatest difference between the two regions.

peaks in the south. Both Langridge et al. (2012) and Metcalf et al. (2012) found significant contributions of nitrate and OC to the aerosol in LA as well. In contrast, previous groundbased measurements in the LA and port of Long Beach areas found higher fractions of sulfate on particles (Pastor et al., 2003; Whiteaker et al., 2002; Qin et al., 2012), and recent findings during the CalNex ship campaign (Gaston et al., 2012) observed a higher abundance of sulfate in southern California than northern California, though the latter is likely more indicative of port regions which are known to 
have large sources of sulfate from ship emissions (Ault et al., 2009).

The contributions of soot and OC to single particle mixing state were found to vary greatly depending upon the region, with soot having a larger influence in the south and OC being more prevalent in the north, as shown by measured OC:soot ion ratio distribution. The largest difference in the nature of particles between southern California and NoCal-1 occurred when the influence of biogenic $\mathrm{OC}$ was the greatest in the north. During this period, the number fraction of OC particles was nearly $18 \%$ higher in the north than in the south. Both NoCal-2 and southern California aerosol exhibited similar chemistry, with most particles containing a soot core with OC, sulfate, and nitrate coatings, though the large difference in magnitude between sulfate and nitrate peaks in each region is a persistent feature. Distributions of OC:soot ratios during NoCal-2 and southern California (Figs. 6 and 9) correlate very well, $R^{2}=0.92$, as compared to NoCal-1 and southern California, $R^{2}=0.56$, highlighting the similarity between NoCal-2 and southern California.

\section{Conclusion}

Two aircraft field campaigns, CalNex and CARES, provide insight into the distribution and mixing state of carbonaceous aerosols in California during the late spring and early summer of 2010. Most submicron particles ( 97\%) in California contain carbonaceous material, and nearly $88 \%$ of all particles show signs of atmospheric aging. Particles are internally mixed with secondary species, including sulfate, nitrate, MSA, OS, and ammonium. Most strikingly, nitrate is more prevalent on particles in southern California, whereas this is the case for sulfate in northern California. This suggests that different sources are impacting particles in the two regions.

OC:soot ion ratio distributions in southern California show that most particles are soot-dominated with an OC coating, whereas OC-dominated particles from biogenic sources are more prevalent in northern California. Single-particle measurements also show that many particles contain both OC and soot, which will lead to increased radiative absorption and scattering (Schnaiter et al., 2005; Schwarz et al., 2008; Moffet and Prather, 2009). A shift in chemistry was observed during the latter half of the CARES campaign, from OCdominant to soot-dominant, as particles in northern California became very similar to particles in southern California. In addition, total $\mathrm{PM}_{2.5}$ reflected this change in particle composition, as $\mathrm{PM}_{2.5}$ concentrations increased significantly in the latter half of the study. This suggests similar particle mixing states are present during periods of relatively higher $\mathrm{PM}_{2.5}$ levels in California. Thus, regionally specific mixing states, as well as temporal changes in mixing state, will need to be taken into account for accurate regional aerosol-climate modeling.

\section{Supplementary material related to this article is available online at: http://www.atmos-chem-phys.net/12/ 10989/2012/acp-12-10989-2012-supplement.pdf.}

Acknowledgements. We would like to acknowledge the University of California San Diego-Pacific Northwest National Laboratory Aerosol Chemistry and Climate Institute and the California Air Resources Board Agreement \#09-333 for providing the funding for this work. Stephen R. Springston provided in flight gas phase concentrations during the CARES campaign. The authors are also grateful to the flight crews during the CARES and CalNex studies, most notably John Hubbe, Jason Tomlinson, Scott Hersey, Andrew Metcalf, and Haflidi Jonsson, as well as Jessie Creamean and Melanie Zauscher of the Prather Group for their help with this project. The Twin Otter portion of this work was supported by NOAA grant NA090AR4310128. Funding for data collection onboard the G-1 aircraft was provided by the Atmospheric Radiation Measurement (ARM) Program sponsored by the US Department of Energy (DOE), Office of Biological and Environmental Research (OBER). This research was also supported by the US DOE's Atmospheric System Research (ASR) Program under Contract DE-AC06-76RLO 1830 at PNNL.

Edited by: D. J. Cziczo

\section{References}

Ackerman, A. S., Toon, O. B., Stevens, D. E., Heymsfield, A. J., Ramanathan, V., and Welton, E. J.: Reduction of tropical cloudiness by soot, Science, 288, 1042-1047, 2000.

Allen, J. O.: YAADA software toolkit to analyze single-particle mass spectral data: Reference manual version 2.11., Arizona State University, http://www.yaada.org, last access: December 2010, 2002.

Angelino, S., Suess, D. T., and Prather, K. A.: Formation of aerosol particles from reactions of secondary and tertiary alkylamines: Characterization by aerosol time-of-flight mass spectrometry, Environ. Sci. Technol., 35, 3130-3138, 2001.

Ault, A. P., Moore, M. J., Furutani, H., and Prather, K. A.: Impact of Emissions from the Los Angeles Port Region on San Diego Air Quality during Regional Transport Events, Environ. Sci. Technol., 43, 3500-3506, doi:10.1021/es8018918, 2009.

Ault, A. P., Gaston, C. J., Wang, Y., Dominguez, G., Thiemens, M. H., and Prather, K. A.: Characterization of the Single Particle Mixing State of Individual Ship Plume Events Measured at the Port of Los Angeles, Environ. Sci. Technol., 44, 1954-1961, doi:10.1021/Es902985h, 2010.

Bahreini, R., Dunlea, E. J., Matthew, B. M., Simons, C., Docherty, K. S., DeCarlo, P. F., Jimenez, J. L., Brock, C. A., and Middlebrook, A. M.: Design and Operation of a PressureControlled Inlet for Airborne Sampling with an Aerodynamic Aerosol Lens, Aerosol Sci. Technol., 42, 465-471, doi:10.1080/02786820802178514, 2008.

Bhave, P. V., Allen, J. O., Morrical, B. D., Fergenson, D. P., Cass, G. R., and Prather, K. A.: A field-based approach for determining ATOFMS instrument sensitivities to ammonium and nitrate, Environ. Sci. Technol., 36, 4868-4879, doi:10.1021/es015823i, 2002. 
Bi, X. H., Zhang, G. H., Li, L., Wang, X. M., Li, M., Sheng, G. Y., Fu, J. M., and Zhou, Z.: Mixing state of biomass burning particles by single particle aerosol mass spectrometer in the urban area of PRD, China, Atmos. Environ., 45, 3447-3453, doi:10.1016/j.atmosenv.2011.03.034, 2011.

Brands, M., Kamphus, M., Böttger, T., Schneider, J., Drewnick, F., Roth, A., Curtius, J., Voigt, C., Borbon, A., Beekmann, M., Bourdon, A., Perrin, T., and Borrmann, S.: Characterization of a Newly Developed Aircraft-Based Laser Ablation Aerosol Mass Spectrometer (ALABAMA) and First Field Deployment in Urban Pollution Plumes over Paris During MEGAPOLI 2009, Aerosol Sci. Technol., 45, 46-64, doi:10.1080/02786826.2010.517813, 2010.

Cappa, C. D., Che, D. L., Kessler, S. H., Kroll, J. H., and Wilson, K. R.: Variations in organic aerosol optical and hygroscopic properties upon heterogeneous $\mathrm{OH}$ oxidation, J. Geophys. Res., 116, D15204, doi:10.1029/2011jd015918, 2011.

Chow, J. C., Watson, J. G., Lowenthal, D. H., Solomon, P. A., Magliano, K. L., Ziman, S. D., and Richards, L. W.: Pm(10) and $\mathrm{Pm}$ (2.5) Compositions in California San Joaquin Valley, Aerosol Sci. Technol., 18, 105-128, 1993.

Chow, J. C., Watson, J. G., Lowenthal, D. H., Chen, L. W. A., Tropp, R. J., Park, K., and Magliano, K. A.: PM 2.5 and PM10 mass measurements in California's San Joaquin Valley, Aerosol Sci. Technol., 40, 796-810, doi:10.1080/02786820600623711, 2006.

Chung, S. H. and Seinfeld, J. H.: Global distribution and climate forcing of carbonaceous aerosols, J. Geophys. Res.-Atmos., 107, 4407, doi:10.1029/2001jd001397, 2002.

Fast, J. D., Gustafson, W. I., Berg, L. K., Shaw, W. J., Pekour, M., Shrivastava, M., Barnard, J. C., Ferrare, R. A., Hostetler, C. A., Hair, J. A., Erickson, M., Jobson, B. T., Flowers, B., Dubey, M. K., Springston, S., Pierce, R. B., Dolislager, L., Pederson, J., and Zaveri, R. A.: Transport and mixing patterns over Central California during the carbonaceous aerosol and radiative effects study (CARES), Atmos. Chem. Phys., 12, 1759-1783, doi:10.5194/acp-12-1759-2012, 2012.

Fergenson, D. P., Pitesky, M. E., Tobias, H. J., Steele, P. T., Czerwieniec, G. A., Russell, S. C., Lebrilla, C. B., Horn, J. M., Coffee, K. R., Srivastava, A., Pillai, S. P., Shih, M. T. P., Hall, H. L., Ramponi, A. J., Chang, J. T., Langlois, R. G., Estacio, P. L., Hadley, R. T., Frank, M., and Gard, E. E.: Reagentless detection and classification of individual bioaerosol particles in seconds, Anal. Chem., 76, 373-378, doi:10.1021/Ac034467e, 2004.

Furutani, H., Dallosto, M., Roberts, G., and Prather, K.: Assessment of the relative importance of atmospheric aging on $\mathrm{CCN}$ activity derived from field observations, Atmos. Environ., 42, 31303142, doi:10.1016/j.atmosenv.2007.09.024, 2008.

Gard, E., Mayer, J. E., Morrical, B. D., Dienes, T., Fergenson, D. P., and Prather, K. A.: Real-time analysis of individual atmospheric aerosol particles: Design and performance of a portable ATOFMS, Anal. Chem., 69, 4083-4091, 1997.

Gard, E. E., Kleeman, M. J., Gross, D. S., Hughes, L. S., Allen, J. O., Morrical, B. D., Fergenson, D. P., Dienes, T., Galli, M. E., Johnson, R. J., Cass, G. R., and Prather, K. A.: Direct observation of heterogeneous chemistry in the atmosphere, Science, 279, 1184-1187, 1998.

Gaston, C. J., Pratt, K. A., Qin, X. Y., and Prather, K. A.: Real-Time Detection and Mixing State of Methanesulfonate in Single Particles at an Inland Urban Location during a Phytoplankton Bloom,
Environ. Sci. Technol., 44, 1566-1572, doi:10.1021/es902069d, 2010.

Gaston, C. J., Quinn, P. K., Timothy, B. S., and Prather, K. A.: Differences in Northern and Southern California particle chemistry and insight into the mixing-state of carbonaceous aerosol in California observed during the CalNex 2010 campaign, in preparation, 2012.

Gross, D. S., Galli, M. E., Silva, P. J., and Prather, K. A.: Relative sensitivity factors for alkali metal and ammonium cations in single particle aerosol time-of-flight mass spectra, Anal. Chem., 72, 416-422, 2000.

Guazzotti, S. A., Coffee, K. R., and Prather, K. A.: Continuous measurements of size-resolved particle chemistry during INDOEXIntensive Field Phase 99, J. Geophys. Res.-Atmos., 106, 2860728627, 2001.

Hand, J. L. and Malm, W. C.: Review of aerosol mass scattering efficiencies from ground-based measurements since 1990, J. Geophys. Res.-Atmos., 112, D16203, doi:10.1029/2007jd008484, 2007.

Hatch, L. E., Creamean, J. M., Ault, A. P., Surratt, J. D., Chan, M. N., Seinfeld, J. H., Edgerton, E. S., Su, Y., and Prather, K. A.: Measurements of Isoprene-Derived Organosulfates in Ambient Aerosols by Aerosol Time-of-Flight Mass Spectrometry - Part 1: Single Particle Atmospheric Observations in Atlanta, Environ. Sci. Technol., 45, 5105-5111, doi:10.1021/es103944a, 2011.

Hudson, P. K., Murphy, D. M., Cziczo, D. J., Thomson, D. S., de Gouw, J. A., Warneke, C., Holloway, J., Jost, J. R., and Hubler, G.: Biomass-burning particle measurements: Characteristic composition and chemical processing, J. Geophys. Res.-Atmos., 109, D23S27, doi:10.1029/2003jd004398, 2004.

Jacobson, M. C., Hansson, H. C., Noone, K. J., and Charlson, R. J.: Organic atmospheric aerosols: Review and state of the science, Rev. Geophys., 38, 267-294, 2000.

Jacobson, M. Z.: Strong radiative heating due to the mixing state of black carbon in atmospheric aerosols, Nature, 409, 695-697, 2001.

Kanakidou, M., Seinfeld, J. H., Pandis, S. N., Barnes, I., Dentener, F. J., Facchini, M. C., Van Dingenen, R., Ervens, B., Nenes, A., Nielsen, C. J., Swietlicki, E., Putaud, J. P., Balkanski, Y., Fuzzi, S., Horth, J., Moortgat, G. K., Winterhalter, R., Myhre, C. E. L., Tsigaridis, K., Vignati, E., Stephanou, E. G., and Wilson, J.: Organic aerosol and global climate modelling: a review, Atmos. Chem. Phys., 5, 1053-1123, doi:10.5194/acp-5-1053-2005, 2005.

Khalizov, A. F., Zhang, R. Y., Zhang, D., Xue, H. X., Pagels, J., and McMurry, P. H.: Formation of highly hygroscopic soot aerosols upon internal mixing with sulfuric acid vapor, J. Geophys. Res.Atmos., 114, D05208, doi:10.1029/2008jd010595, 2009.

Kleeman, M. J. and Cass, G. R.: Source contributions to the size and composition distribution of urban particulate air pollution, Atmos. Environ., 32, 2803-2816, 1998.

Kloster, S., Dentener, F., Feichter, J., Raes, F., Lohmann, U., Roeckner, E., and Fischer-Bruns, I.: A GCM study of future climate response to aerosol pollution reductions, Clim. Dynam., 34, $1177-$ 1194, doi:10.1007/s00382-009-0573-0, 2010.

Koch, D., Balkanski, Y., Bauer, S. E., Easter, R. C., Ferrachat, S., Ghan, S. J., Hoose, C., Iversen, T., Kirkevag, A., Kristjansson, J. E., Liu, X., Lohmann, U., Menon, S., Quaas, J., Schulz, M., Seland, O., Takemura, T., and Yan, N.: Soot microphysical effects 
on liquid clouds, a multi-model investigation, Atmos. Chem. Phys., 11, 1051-1064, doi:10.5194/acp-11-1051-2011, 2011.

Langridge, J. M., Lack, D., Brock, C. A., Bahreini, R., Middlebrook, A. M., Neuman, J. A., Nowak, J. B., Perring, A. E., Schwarz, J. P., Spackman, J. R., Holloway, J. S., Pollack, I. B., Ryerson, T. B., Roberts, J. M., Warneke, C., de Gouw, J. A., Trainer, M. K., and Murphy, D. M.: Evolution of aerosol properties impacting visibility and direct climate forcing in an ammonia-rich urban environment, J. Geophys. Res.-Atmos., 117, D00v11, doi:10.1029/2011jd017116, 2012.

Leibensperger, E. M., Mickley, L. J., Jacob, D. J., Chen, W. T., Seinfeld, J. H., Nenes, A., Adams, P. J., Streets, D. G., Kumar, N., and Rind, D.: Climatic effects of 1950-2050 changes in US anthropogenic aerosols - Part 2: Climate response, Atmos. Chem. Phys., 12, 3349-3362, doi:10.5194/acp-12-3349-2012, 2012.

Liu, P., Ziemann, P. J., Kittelson, D. B., and Mcmurry, P. H.: Generating Particle Beams of Controlled Dimensions and Divergence 1: Theory of Particle Motion in Aerodynamic Lenses and Nozzle Expansions, Aerosol Sci. Technol., 22, 293-313, 1995a.

Liu, P., Ziemann, P. J., Kittelson, D. B., and Mcmurry, P. H.: Generating Particle Beams of Controlled Dimensions and Divergence - 2: Experimental Evaluation of Particle Motion in Aerodynamic Lenses and Nozzle Expansions, Aerosol Sci. Technol., 22, 314 324, 1995 b.

Metcalf, A. R., Craven, J. S., Ensberg, J. J., Brioude, J., Angevine, W., Sorooshian, A., Duong, H. T., Jonsson, H. H., Flagan, R. C., and Seinfeld, J. H.: Black carbon aerosol over the Los Angeles Basin during CalNex, J. Geophys. Res., 117, D00V13, doi:10.1029/2011jd017255, 2012.

Mickley, L. J., Leibensperger, E. M., Jacob, D. J., and Rind, D.: Regional warming from aerosol removal over the United States: Results from a transient 2010-2050 climate simulation, Atmos. Environ., 46, 545-553, doi:10.1016/j.atmosenv.2011.07.030, 2012.

Mochida, M., Kuwata, M., Miyakawa, T., Takegawa, N., Kawamura, K., and Kondo, Y.: Relationship between hygroscopicity and cloud condensation nuclei activity for urban aerosols in Tokyo, J. Geophys. Res.-Atmos., 111, D23204, doi:10.1029/2005jd006980, 2006.

Moffet, R. C. and Prather, K. A.: In-situ measurements of the mixing state and optical properties of soot with implications for radiative forcing estimates, Proc. Natl. Acad. Sci. USA, 106, 11872-11877, doi:10.1073/pnas.0900040106, 2009.

Moffet, R. C., Henn, T., Laskin, A., and Gilles, M. K.: Automated Chemical Analysis of Internally Mixed Aerosol Particles Using X-ray Spectromicroscopy at the Carbon K-Edge, Anal. Chem., 82, 7906-7914, doi:10.1021/Ac1012909, 2010.

Morrical, B. D., Fergenson, D. P., and Prather, K. A.: Coupling twostep laser desorption/ionization with aerosol time-of-flight mass spectrometry for the analysis of individual organic particles, J. Am. Soc. Mass Spectrom., 9, 1068-1073, 1998.

Murphy, D. M. and Thomson, D. S.: Laser Ionization Mass Spectroscopy of Single Aerosol Particles, Aerosol Sci. Technol., 22, 237-249, doi:10.1080/02786829408959743, 1995.

Murphy, D. M., Cziczo, D. J., Hudson, P. K., and Thomson, D. S.: Carbonaceous material in aerosol particles in the lower stratosphere and tropopause region, J. Geophys. Res., 112, D15204, doi:10.1029/2006jd007297, 2007.

Naoe, H., Hasegawa, S., Heintzenberg, J., Okada, K., Uchiyama, A., Zaizen, Y., Kobayashi, E., and Yamazaki, A.: State of mixture of atmospheric submicrometer black carbon particles and its effect on particulate light absorption, Atmos. Environ., 43, 1296-1301, doi:10.1016/j.atmosenv.2008.11.031, 2009.

Neubauer, K. R., Johnston, M. V., and Wexler, A. S.: On-line analysis of aqueous aerosols by laser desorption ionization, Int. J. Mass Spectrom. Ion Proc., 163, 29-37, 1997.

Neubauer, K. R., Johnston, M. V., and Wexler, A. S.: Humidity effects on the mass spectra of single aerosol particles, Atmos. Environ., 32, 2521-2529, 1998.

Noble, C. A. and Prather, K. A.: Real-time measurement of correlated size and composition profiles of individual atmospheric aerosol particles, Environ. Sci. Technol., 30, 2667-2680, 1996.

Pastor, S. H., Allen, J. O., Hughes, L. S., Bhave, P., Cass, G. R., and Prather, K. A.: Ambient single particle analysis in Riverside, California by aerosol time-of-flight mass spectrometry during the SCOS97-NARSTO, Atmos. Environ., 37, 239-258, doi:10.1016/s1352-2310(03)00393-5, 2003.

Petters, M. D., Prenni, A. J., Kreidenweis, S. M., DeMott, P. J., Matsunaga, A., Lim, Y. B., and Ziemann, P. J.: Chemical aging and the hydrophobic-to-hydrophilic conversion of carbonaceous aerosol, Geophys. Res. Lett., 33, L24806, doi:10.1029/2006g1027249, 2006.

Pöschl, U.: Atmospheric aerosols: composition, transformation, climate and health effects, Angew. Chemie, 44, 7520-7540, doi:10.1002/anie.200501122, 2005.

Prather, K. A., Hatch, C. D., and Grassian, V. H.: Analysis of atmospheric aerosols, Annu. Rev. Anal. Chem. (Palo Alto Calif), 1, 485-514, doi:10.1146/annurev.anchem.1.031207.113030, 2008.

Pratt, K. A. and Prather, K. A.: Real-Time, Single-Particle Volatility, Size, and Chemical Composition Measurements of Aged Urban Aerosols, Environ. Sci. Technol., 43, 8276-8282, doi:10.1021/es902002t, 2009.

Pratt, K. A. and Prather, K. A.: Aircraft measurements of vertical profiles of aerosol mixing states, J. Geophys. Res., 115, D11305, doi:10.1029/2009jd013150, 2010.

Pratt, K. A., Mayer, J. E., Holecek, J. C., Moffet, R. C., Sanchez, R. O., Rebotier, T. P., Furutani, H., Gonin, M., Fuhrer, K., Su, Y., Guazzotti, S., and Prather, K. A.: Development and Characterization of an Aircraft Aerosol Time-of-Flight Mass Spectrometer, Anal. Chem., 81, 1792-1800, doi:10.1021/ac801942r, 2009.

Qin, X., Pratt, K. A., Shields, L. G., Toner, S. M., and Prather, K. A.: Seasonal Comparisons of Single-Particle Chemical Mixing State in Riverside, CA, submitted to Atmos. Environ., 2012.

Ramanathan, V. and Carmichael, G.: Global and regional climate changes due to black carbon, Nature Geosci., 1, 221-227, doi:10.1038/ngeo156, 2008.

Ramanathan, V., Ramana, M. V., Roberts, G., Kim, D., Corrigan, C., Chung, C., and Winker, D.: Warming trends in Asia amplified by brown cloud solar absorption, Nature, 448, 575-578, doi:10.1038/nature06019, 2007.

Rebotier, T. P. and Prather, K. A.: Aerosol time-of-flight mass spectrometry data analysis: a benchmark of clustering algorithms, Analytica chimica acta, 585, 38-54, doi:10.1016/j.aca.2006.12.009, 2007.

Reid, J. S., Koppmann, R., Eck, T. F., and Eleuterio, D. P.: A review of biomass burning emissions part II: intensive physical properties of biomass burning particles, Atmos. Chem. Phys., 5, 799825, doi:10.5194/acp-5-799-2005, 2005. 
Riemer, N., West, M., Zaveri, R., and Easter, R.: Estimating black carbon aging time-scales with a particle-resolved aerosol model, Journal of Aerosol Science, 41, 143-158, doi:10.1016/j.jaerosci.2009.08.009, 2010.

Rosenfeld, D. and Givati, A.: Evidence of orographic precipitation suppression by air pollution-induced aerosols in the western United States, J. Appl. Meteorol. Climatol., 45, 893-911, 2006.

Rudich, Y., Donahue, N. M., and Mentel, T. F.: Aging of organic aerosol: bridging the gap between laboratory and field studies, Annu Rev Phys Chem, 58, 321-352, doi:10.1146/annurev.physchem.58.032806.104432, 2007.

Russell, S. C.: Microorganism characterization by single particle mass spectrometry, Mass Spectrom. Rev., 28, 376-387, doi:10.1002/mas.20198, 2009.

Schnaiter, M., Linke, C., Mohler, O., Naumann, K. H., Saathoff, H., Wagner, R., Schurath, U., and Wehner, B.: Absorption amplification of black carbon internally mixed with secondary organic aerosol, J. Geophys. Res.-Atmos., 110, D19204, doi:10.1029/2005jd006046, 2005.

Schultz, P. and Warner, T. T.: Characteristics of Summertime Circulations and Pollutant Ventilation in the Los-Angeles Basin, J. Appl. Meteorol., 21, 672-682, 1982.

Schwarz, J. P., Spackman, J. R., Fahey, D. W., Gao, R. S., Lohmann, U., Stier, P., Watts, L. A., Thomson, D. S., Lack, D. A., Pfister, L., Mahoney, M. J., Baumgardner, D., Wilson, J. C., and Reeves, J. M.: Coatings and their enhancement of black carbon light absorption in the tropical atmosphere, J. Geophys. Res.-Atmos., 113, D03203, doi:10.1029/2007jd009042, 2008.

Setyan, A., Zhang, Q., Merkel, M., Knighton, W. B., Sun, Y., Song, C., Shilling, J. E., Onasch, T. B., Herndon, S. C., Worsnop, D. R., Fast, J. D., Zaveri, R. A., Berg, L. K., Wiedensohler, A., Flowers, B. A., Dubey, M. K., and Subramanian, R.: Characterization of submicron particles influenced by mixed biogenic and anthropogenic emissions using high-resolution aerosol mass spectrometry: results from CARES, Atmos. Chem. Phys., 12, 8131-8156, doi:10.5194/acp-12-8131-2012, 2012.

Silva, P. J. and Prather, K. A.: Interpretation of Mass Spectra from Organic Compounds in Aerosol Time-of-Flight Mass Spectrometry, Anal. Chem., 72, 3553-3562, doi:10.1021/ac9910132, 2000.

Silva, P. J., Liu, D. Y., Noble, C. A., and Prather, K. A.: Size and chemical characterization of individual particles resulting from biomass burning of local Southern California species, Environ. Sci. Technol., 33, 3068-3076, 1999.

Singh, M., Jaques, P. A., and Sioutas, C.: Size distribution and diurnal characteristics of particle-bound metals in source and receptor sites of the Los Angeles Basin, Atmos. Environ., 36, 16751689,2002

Song, X. H., Hopke, P. K., Fergenson, D. P., and Prather, K. A.: Classification of single particles analyzed by ATOFMS using an artificial neural network, ART-2A, Anal. Chem., 71, 860-865, 1999.

Sorooshian, A., Murphy, S. N., Hersey, S., Gates, H., Padro, L. T., Nenes, A., Brechtel, F. J., Jonsson, H., Flagan, R. C., and Seinfeld, J. H.: Comprehensive airborne characterization of aerosol from a major bovine source, Atmos. Chem. Phys., 8, 5489-5520, 2008 ,

http://www.atmos-chem-phys.net/8/5489/2008/.
Spencer, M. T. and Prather, K. A.: Using ATOFMS to determine OC/EC mass fractions in particles, Aerosol Sci. Technol., 40, 585-594, doi:10.1080/02786820600729138, 2006.

Steele, P. T., Tobias, H. J., Fergenson, D. P., Pitesky, M. E., Horn, J. M., Czerwieniec, G. A., Russell, S. C., Lebrilla, C. B., Gard, E. E., and Frank, M.: Laser power dependence of mass spectral signatures from individual bacterial spores in bioaerosol mass spectrometry, Anal. Chem., 75, 5480-5487, doi:10.1021/Ac034419u, 2003.

Ulrickson, B. L. and Mass, C. F.: Numerical Investigation of Mesoscale Circulations over the Los-Angeles Basin .2. Synoptic Influences and Pollutant Transport, Mon. Weather Rev., 118, 2162-2184, 1990.

Wang, J., Cubison, M. J., Aiken, A. C., Jimenez, J. L., and Collins, D. R.: The importance of aerosol mixing state and size-resolved composition on $\mathrm{CCN}$ concentration and the variation of the importance with atmospheric aging of aerosols, Atmos. Chem. Phys., 10, 7267-7283, doi:10.5194/acp-10-7267-2010, 2010.

Wenzel, R. J. and Prather, K. A.: Improvements in ion signal reproducibility obtained using a homogeneous laser beam for on-line laser desorption/ionization of single particles, Rapid Communications in Mass Spectrometry, 18, 1525-1533, doi:10.1002/rcm.1509, 2004.

Whiteaker, J. R., Suess, D. T., and Prather, K. A.: Effects of meteorological conditions on aerosol composition and mixing state in Bakersfield, CA, Environ. Sci. Technol., 36, 2345-2353, doi:10.1021/Es011381z, 2002.

Ying, Q. and Kleeman, M. J.: Source contributions to the regional distribution of secondary particulate matter in California, Atmos. Environ., 40, 736-752, doi:10.1016/j.atmosenv.2005.10.007, 2006.

Zaremba, L. L. and Carroll, J. J.: Summer wind flow regimes over the Sacramento Valley, J. Appl. Meteorol., 38, 1463-1473, 1999.

Zaveri, R. A., Barnard, J. C., Easter, R. C., Riemer, N., and West, M.: Particle-resolved simulation of aerosol size, composition, mixing state, and the associated optical and cloud condensation nuclei activation properties in an evolving urban plume, J. Geophys. Res.-Atmos., 115, D17210, doi:10.1029/2009jd013616, 2010.

Zaveri, R. A., Shaw, W. J., Cziczo, D. J., Schmid, B., Ferrare, R. A., Alexander, M. L., Alexandrov, M., Alvarez, R. J., Arnott, W. P., Atkinson, D. B., Baidar, S., Banta, R. M., Barnard, J. C., Beranek, J., Berg, L. K., Brechtel, F., Brewer, W. A., Cahill, J. F., Cairns, B., Cappa, C. D., Chand, D., China, S., Comstock, J. M., Dubey, M. K., Easter, R. C., Erickson, M. H., Fast, J. D., Floerchinger, C., Flowers, B. A., Fortner, E., Gaffney, J. S., Gilles, M. K., Gorkowski, K., Gustafson, W. I., Gyawali, M., Hair, J., Hardesty, R. M., Harworth, J. W., Herndon, S., Hiranuma, N., Hostetler, C., Hubbe, J. M., Jayne, J. T., Jeong, H., Jobson, B. T., Kassianov, E. I., Kleinman, L. I., Kluzek, C., Knighton, B., Kolesar, K. R., Kuang, C., KubC!tovC, A., Langford, A. O., Laskin, A., Laulainen, N., Marchbanks, R. D., Mazzoleni, C., Mei, F., Moffet, R. C., Nelson, D., Obland, M. D., Oetjen, H., Onasch, T. B., Ortega, I., Ottaviani, M., Pekour, M., Prather, K. A., Radney, J. G., Rogers, R. R., Sandberg, S. P., Sedlacek, A., Senff, C. J., Senum, G., Setyan, A., Shilling, J. E., Shrivastava, M., Song, C., Springston, S. R., Subramanian, R., Suski, K., Tomlinson, J., Volkamer, R., Wallace, H. W., Wang, J., Weickmann, A. M., Worsnop, D. R., Yu, X. Y., Zelenyuk, A., and Zhang, 
Q.: Overview of the 2010 Carbonaceous Aerosols and Radiative Effects Study (CARES), Atmos. Chem. Phys., 12, 7647-7687, doi:10.5194/acp-12-7647-2012, 2012.

Zelenyuk, A. and Imre, D.: Single particle laser ablation time-offlight mass spectrometer: An introduction to SPLAT, Aerosol Sci. Technol., 39, 554-568, doi:10.1080/027868291009242, 2005.
Zelenyuk, A., Imre, D., Earle, M., Easter, R., Korolev, A., Leaitch, R., Liu, P., Macdonald, A. M., Ovchinnikov, M., and Strapp, W.: In situ characterization of cloud condensation nuclei, interstitial, and background particles using the single particle mass spectrometer, SPLAT II, Anal. Chem., 82, 7943-7951, doi:10.1021/ac1013892, 2010. 